\title{
Perencanaan Peningkatan Mutu Guru Madrasah Salafiyah Wustha Desa Batu Madinding Kecamatan Batang Natal Kabupaten Mandailing Natal
}

\author{
Siti Hawa \\ Universitas Medan Area \\ lubis sitihawa@yahoo.com
}

\begin{abstract}
Abstrak
Penelitian ini bertujuan untuk mengetahui perencanaan guru di Madrasah Salafiyah Wustha Batu Madinding Kecamatan Batang Natal Kabupaten Mandailing Natal, dengan menggunakan metode penelitian kualitatif.Subjek dalam penelitian ini adalah 1 orang kepala sekolah, dan 5 orang guru sebagai sample dalam penelitian, sedangkan teknik pengumpulan data dilakukan dengan teknik wawancara, observasi dan studi dokumen, untuk menganalisis data digunakan reduksi data, penyajian data dan verifikasi data (kesimpulan). Hasil penelitian mengungkapkan temuan bahwa perencanaan peningkatan mutu guru di Madrasah Salafiyah Wustha Batu Madinding dilaksanakan dengan rapat melibatkan seluruh komponen madrasah seperti kepala madrasah, wakil kepala madrasah, staf dan guru-guru.Seluruh komponen ini saling bekerjasama dalam merencanakan program kerja yang akan dilaksanakan guna meningkatkan mutu guru.
\end{abstract}

Kata Kunci : Manajemen, Peningkatan Mutu dan Guru.

\begin{abstract}
This study aims to determine teacher planning at Madrasah Salafiyah Wustha Batu Mawall, Batang Natal District, Mandailing Natal Regency, using qualitative research methods. with interview, observation and document study techniques, to analyze the data used data reduction, data presentation and data verification (conclusions). The results of the study revealed the findings that the planning for improving the quality of teachers at Madrasah Salafiyah Wustha Batu Mawall was carried out in a meeting involving all components of the madrasa such as the head of the madrasa, deputy head of the madrasa, staff and teachers. teacher quality.
\end{abstract}

Keywords: Management, Quality Improvement and Teachers.

\section{Pendahuuan}

Pendidikan nasional berfungsi mengembangkan kemampuan dan membentuk watak serta peradaban bangsa yang bermartabat dalam rangka mencerdaskan kehidupan bangsa, bertujuan untuk berkembangnya potensi peserta didik agar menjadi manusia yang beriman dan bertakwa kepada Tuhan Yang Maha Esa, berakhlak mulia, sehat, berilmu, cakap, kreatif, mandiri, dan menjadi warga negara yang demokratis serta bertanggung jawab(Jalil, 2012).

Pendidikan merupakan kebutuhan pundamentel di setiap jenjang dan lapisan masyarakat dalam membentuk karakter manusia "seperti Pesantren, Sekolah dan Madrasah merupakan lembaga penyelenggara pendidikan di Indonesia. Masing-masing 
lembaga pendidikan tersebut telah diatur dan diakui oleh pemerintah dalam undangundang Nomor 20 Tahun 2003 tentang Sistem Pendidikan Nasional. Pesantren ditetapkan sebagai salah satu bentuk lembaga pendidikan keagamaan (Pasal 30 ayat 4). Sedangkan Sekolah dan Madrasah merupakan lembaga pendidikan formal yang mempunyai jenjang pendidikan dasar dan menengah (Pasal 17 dan 18).

Berdasarkan uraian di atas Pesantren, Sekolah dan Madrasah merupakan lembaga penyelenggara pendidikan di Indonesia yang diatur dan diakui oleh pemerintah. Secara historis kemunculan ketiga lembaga tersebut mempunyai hubungan antara satu dengan lainnya sehingga mempunyai ciri khas masing-masing.Sebagai sebuah sistem pendidikan ketiga lembaga tersebut mempunyai komponen input, proses dan output. Ketiga komponen tersebut harus dikelola dan diatur dengan manajemen yang professional untukmenghasilkan penyelenggaraan pendidikan yangbermutu dan berkualitas baik bagi guru atau siswa (Masyfu, 2017). Dalam perjalanannya ketiga lembaga tersebut selalu dihadapkan dengan berbagai problem dalam pengembangannya, baik problem di dalam input, proses ataupun outputnya. Identifikasi terhadap problematika yang ada merupakan langkah awal dalam upaya perbaikan secara terus-menerus terhadap mutu dan kualitas lembaga-lembaga pendidikan tersebut. Begitu juga pendidikan di Pesantren menjadi bagian infrastruktur masyarakat yang secara makro telah berperan menyadarkanmasyarakat untuk memilikiidealisme, kemampuan intelektual, dan perilakuyang baikguna menata dan membangun karakter bangsa. Pesantren secara berkesinambunganberusahamembentukperilakumasyarakatnya (Siswanto, 2015).

Berdasarkan pendapat di atas bahwa pendidikan yang dianggap sebagai suatu investasi yang paling berharga dalam bentuk peningkatan kualitas sumber daya insani (mutu) yang paling berharga dalam bentuk peningkatan kualitas sumber daya insani untuk pembangunan suatu bangsa. Kualitas pendidikan tidak saja dilihat dari kemegahan fasilitas pendidikan yang dimiliki, tetapi sejauh mana output (lulusan) suatu pendidikan dapat membangun sebagai manusia yang paripurna sebagaimana tahapan proses pelaksanaan pendidikan tersebut. Demikian pendapat di atas selain tata kelola manajemen sangat penting mengusahakan peserta didik yang bermutu, kurikulum yang bermutu, fasilitas yang bermutu dan berbagai aspek penyelenggaraan pendidikan yang bermutu. Proses pendidikan yang bermutu adalah proses pembelajaran yang bermutu. Output pendidikan yang bermutu adalah lulusan yang memiliki kompetensi yang disyaratkan.

Guru adalah seorang pengajar yang wajib ditiru dan dihormati oleh setiap peserta didik. Dalam proses kegiatan belajar mengajar, guru sangat penting peranannya dalam penyelenggaraan tersebut, pasalnya semua materi pengajaran yang ada di setiap sekolah semuanya disampaikan oleh guru. Dan agar setiap penyelenggaraan kegiatan belajar mengajar dapat berjalan dengan baik dan lancar maka dibutuhkanlah guru yang berkualitas. Memang kualitas guru yang baik dan cemerlang akan membawa dampak yang baik pula pada kualitas pendidikan di Indonesia (Makhmudah, 2016).

Dalam hal ini khususnya Pesantren Thoriqotul Mardiyah,perlu meningkatkan bagaimana upaya-upaya meningkatkan mutu guru penting untuk selalu dilaksanakan secara formal maupun non formal baik bekerja sama dengan pemerintah maupun oleh 
pesantren atau guru atas kesadaran sendiri agar kompetensi seorang guru baik kompetensi kepribadian maupun kompetensi professional tetap terjaga bahkan meningkat dari waktu ke waktu.

Dikeluarkannya Undang-Undang karena secara profesional guru di negara kita masih belum memenuhi harapan dan dari segi kuantitatif jumlah guru masih belum memadai terutama guru agama (Azra, 2000). Sehingga diharapkan guru harus bersikap profesional dalam menjalankan tugas dalam proses belajar mengajar. Karena yang dikatakan guru yang bermutu, yaitu guru yang mempunyai karakteristik, sebagai berikut: (1) mengembangkan sumber belajar, (2) menciptakan kelas kondusif, (3) menciptakan kelas interaktif, (4) teknik kuis, (5) memanfaatkan media belajar, (6) pengembangan media belajar, (7) pemanfaatan sumber belajar, (8) memanfaatkan potensi lingkungan sekolah sebagai sumber belajar, (9) strategi motivasi, (10) membimbing siswa untuk berkarya, (11) menciptakan suasana kelas yang komptetitif, (12) Diskusi dan kolaborasi antarteman sejawat, (13) diskusi dan kolaborasi dalamorganisasi profesi, (14) aktif dan produktif,(15) mengembangkan materi, dan (16) melakukan penelitian (Jatirahayu, 2013).

Untuk mencapai guru yang berkualitas, guru perlu dibekali berbagai ilmu, ketrampilan dan keahlian sesuai dengan kompetensinya. Mutu dalam pendidikan memiliki karakteristik yang khas, karena pendidikan bukanlah industri.Dalam pendidikan, produk pendidikan itu bukanlah goods (barang) tetapi services (layanan).Namun demikian, para ahli pendidikan dalam manajemen mutu terpadu (MMT) setidaknya menerapkan lima pilar, diantaranya: 1) fokus pada customer, 2) keterlibatan total, 3) pengukuran, 4) komitmen dan 5) perbaikan berkelanjutan (Ijudin, 2015).

Sejalan dengan uraian diatas bahwa lembaga pendidikan merupakan hal pentinguntuk mewujudkan pendidikan yang bermutu, pemerintah melalui Badan Nasional Standar Pendidikan (BSNP) telah mengeluarkan UU No. 19 Tahun 2005 tentang 8 Standar Nasional Pendidikan (SNP) yang melputi: 1) Standar Kompetensi Lulusan; 2) Standar Isi; 3) Standar Proses; 4) Standar Pendidik dan Tenaga Kependidikan; 5) Standar Saran dan Prasarana; 6) Standar Pengelolaan; 7) Standar Pembiayaan Pendidikan; dan 8) standar Penilaian Pendidikan.

Adapun Fungsi dan Tujuan SNP adalah: a) Sebagai dasar dalam perncanaan, pelaksanaan, dan pengawasan pendidikan dalam rangka mewujudkan pendidikan nasional yang bermutu; b) Menjamin mutu pendidikan nasional dalam rangka mencerdaskan kehidupan bangsa dan membentuk watak serta peradaban bangsa yang bermartabat; c) SNP disempurnakan secara terencana, terarah, dan berkelanjutan sesuai dengan tuntutan peradaban kehidupan lokal, nasional, dan global (Nurfaidah Samad, 2019).

Dewasa ini, mutu dalam arti kata, mereka dapat bekerja dengan profesional, sesuai dengan fungsi dan tanggungjawab. Begitu juga bagi pimpinan pondok pesantren dapat bekerja secara profesional untuk memenuhi kebutuhan profesionalisme para guru/ustadz, baik pelayanan, pendidikan, kesehatan, fasilitas, dan yang tidak kalah penting adalah aspek 
ekonomi atau kebutuhan hidup saat ini dan masa akan dating (Mubarok, 2016).

Salah satunya memuat Standar pendidik yang dijadikan sebagai acuan standar yang harus dimiliki oleh seorang guru atau pendidik dalam peningkatan profesionalitas pendidik dalam lembaga pendidikan di Indonesia.Dan pada bulan Desember 2005 pemerintah juga telah mengeluarkan Undang-Undang tentang Guru-Dosen dalam UU No.14/2005. Undang-undang ini dikeluarkan untuk mengatur guru dan dosen pendidikan di Indonesia. Adapun latar belakang diterbitkannya UU ini adalah "guru dan dosen mempunyai fungsi, peran, dan kedudukan yang sangat strategis dalam pembangunan nasional dalam bidang pendidikan, sehingga perlu dikembangkan sebagai profesi yang bermartabat"( Undang-Undang No.14/2005).

Oleh karena itu, guru sebagai suatu profesi harus professional dalam melaksanakan berbagai tugas pendidikan dan pengajaran, pembimbingan dan pelatihan yang diamanahkan kepadanya (Hadis \& Nurhayati). Tenaga pendidik (guru) mempunyai arti penting dalam melaksanakan proses pembelajaran.Khususnya dalam mewujudkan pendidikan nasional.

Berdasarkan hasil observasi yang dilakukan, sebagai hipotesis awal, penulis mendapati bahwa di Madarasah Salafiyah Pondok Pesantren Thoriqotul Mardiyah masih penting dalam peningkatan ilmu pengetahuan sesuai dengan tuntutan zaman. di Madarasah Salafiyah Pondok Pesantren Thoriqotul Mardiyah memiliki guru sebanyak 17 orang dan jumlah tersebut mencapai hampir keseluruhan guru yang ada di Madarasah Salafiyah Pondok Pesantren Thoriqotul Mardiyah belum memiliki kualifikasi pendidikan S1. Dari 17 jumlah guru baru tujuh orang yang sudah sarjana sedangkan sisanya masih SLTA sederajat.

Selain itu, di Madarasah Salafiyah Pondok Pesantren Thoriqotul Mardiyah termasuk salah satu lembaga pendidikan salafiyah yang terus berupaya melakukan peningkatan mutu para tenaga pendidiknya. Hal ini terlihat melalui program-program pembinaan guru yang diselenggarakan oleh di Madarasah Salafiyah Pondok Pesantren Thoriqotul Mardiyah tersebut. Seperti misalnya Pelatihan, Studi banding dan Workshop Kurikulum 2013 (K-13), KBK, KTSP yang diselenggarakan dalam rangka untuk meningkatkan kualitas guru dalam menjalankan tugas dan peranannya sebagai tenaga pendidik agar terwujud tujuan dari pendidikan nasional. Pelaksanaan berbagai program tersebut dapat dipahami sebagai salah satu fungsi manajemen yang dilakukan oleh kepala di Madarasah Salafiyah Pondok Pesantren Thoriqotul Mardiyah dalam peningkatkan mutu guru.

Lebih lanjut mengenai peningkatan mutu guru di Madarasah Salafiyah Pondok Pesantren ThoriqotulMardiyah,fenomena menunjukkan bahwa masih terdapatnya kinerja yang kurang optimal di kalangan para guru. Hal ini setidaknya terlihat dari dua hal sebagai berikut: pertama, guru yang sudah sarjana masih belum mampu meningkatkan kinerjanya; kedua, masih banyaknya guru belum mengoptimalkan perangkat IT dan alat peraga lainnya untuk mendukung kegiatan belajar dan mengajar, sehingga hanya mengandalkan penggunaan metode ceramah dan mencatat; dan ketiga, kurangnya peran guru dalam melakukan perbaikan sistem pembelajaran 
melalui penelitian tindakan kelas dan perangkat pembelajaran seperti RPP, bahan ajar, media pembelajaran, dan instrumen evaluasi yang belum disusun dengan baik.

Dengan demikian, peran kepala di Madarasah Salafiyah Pondok Pesantren Thoriqotul Mardiyah sangat dibutuhkan untuk dapat membantu peningkatan mutu guru guna mewujudkan mutu pendidikan yang berkualitas. Oleh sebab itu, berdasarkan hasil pengamatan yang dilakukan oleh penulis serta uraian fakta di atas, juga mengingat pentingnya manajemen mutu gurudalam mengatur penyelenggaraan lembaga pendidikan tersebut, maka peneliti tertarik untuk melakukan penelitian tentang.

\section{Jenis Penelitian}

Penelitian ini termasuk ke dalam penelitian kualitatif fenomenologis. Dikatakan demikian karena tempat dan waktu penelitian ini mempunyai ciri-ciri antara lain setting yang actual, peneliti adalah instrumen kunci, data bersifat deskriptif, menekankan kepada proses, analisis datanya bersifat induktif, dan meaning (pemaknaan) tiap peristiwa adalah merupakan perhatian yang esensial dalam penelitian kualitatif(Sujana, 2006).

Dikatan fenomenologis, karena sesuai dengan tujuan penelitian yaitu mendeskripsikan peristiwa social, dengan cara mengungkapkan peristiwa-peristiwa factual dilapangan dan mengungkapkan nilai-nilai yang tersembunyi (hiddenvalue), lebih peka terhadap informasi-informasi yang bersifat deskriptif dan berusaha mempertahankan keutuhan objek yang diteliti(Sujana, 2006).

\section{Hasil Penelitian}

Perencanaan merupakan hal yang sangat penting dalam melakukan suatu pekerjaan. Begitu juga halnya pada Manajemen Peningkatan Mutu guru. Adapun bentuk yang dijadikan landasan dalam strategi manajemen peningkatan mutu guru di Sekolah. Berdasarkan hasil wawancara peneliti dengan H.Alinuh Lubis menjelaskan bahwa perencanaan Manajemen Peningkatan Mutu Guru pada Madrasah Salafiyah Wustha Batu Madinding Kabupaten Mandailing Natal dilaksanakan sesuai dengan isi kandungan visi dan misi dan berbagai pertimbangan. Adapun beberapa pertimbangan yang dimaksud seperti pendanaan, waktu, serta kemungkinan sumber daya yang dimiliki di Madrasah Salafiyah Wustha Batu MadindingKabupaten Mandailing Natal (hasil wawancara dengan kepala madrasah, 2020).

Sebelum mengarahkan dan mengawasi, harus ada rencana yang memberikan tujuan dan arah suatu program. Perencanaan adalah pemilihan dan penetapan kegiatan, selanjutnya apa yang harus dilakukan, kapan, bagaimana dan oleh siapa.

Sejalan dengan uraian di atas pimpinan Madrasah selalu melakukan sosialisasi kepada guru-guru ketika ada suatu perencanaandalam rangka peningkatan mutu guru, dari pihak madrasah, maka para guru selalu diminta saran, pendapat, maupun idenya mengenai perencanaan tersebut, dan biasanya sosialisasi ini dibuat dalam bentuk rapat kerja antara pimpinan dengan para staf dan guru-guru (hasil dokumentasi rapat kerja Madrasah Salafiyah Batu Madinding, 2020).

Berdasarkan pendapat di atas pimpinan dalam pembuatan keputusan, proses pengembangan dan penyeleksian program dan sekumpulan kegiatan untuk memecahkan 
suatu masalah tertentu mengadakan keterbukaan sifat antara sesama, guna menghindari ketidaksenjangan ke pemimpinan nya, tentunya dalam hal ini secara kognitif yang lebih banyak tanggungjawabnya untuk menyelesaiakan permasalahan yang dihadapi yaitu guru, seperti halnya persoalan siswa.

Biar lebih jelasnya berikut penulis uraikan, bagaimana dampak pentingnya mutu guru, antara lain:

a. Tugas Guru

Guru Sekolah Madrasah Salafiyah Wustha Batu Madindingdibagi menjadi 2, yaitu sebagai Wali Kelas dan pendamping.

1) Tugas Wali Kelas

Memberikan materi pelajaran dengan berbagai variasi atau seni dalam kegiatan belajar mengajar, Menyampaikan, memberi tauladan dan memfasilitasi siswasiswa untuk kebutuhan yang baik, Memberikan kenyamanandalam proses kegiatan mengajar (tidak monoton), Bertanggungjawabatas pencapaian hasilbelajar siswa, Bertanggungjawab kepada wali siswa dan kepala sekolah.

2) Tugas Pendamping

Memberikan materi pelajaran dengan berbagai variasi atau seni dalam kegiatan belajar mengajar, Menyampaikan, memberi tauladan dan memfasilitasi siswasiswa untuk kebutuhan yang baik, Memberikan kenyamanan dalam pembelajaran, (tidak monoton), efektif dan efisien, Membantu wali kelas dalam perencanaan dan administrasi kelas (data observasi, 2020).

Selain tugas guru yang terdapat diatas, di Sekolah Madrasah Salafiyah WusthaBatu Madinding seorang guru mempunyai tugas pribadi untuk guru yaitu seorang guru harus membuat buku peta konsep dan modul / RPSsebagai media pembelajarannya di dalam kelas.Tugas tersebut merupakan salah satu penunjang bagi guru dalam menjalankan tugasnya sebagai seorang pendidik (data observasi, 2020).

Selanjutnya rencana penigkatan mutu guru di Sekolah Madrasah Salafiyah WusthaBatu Madinding yaitu dengan merancang berbagai program pelatihan untuk guru.Program pelatihan guru dan manajemen peningkatan mutu guru di Sekolah Madrasah Salafiyah WusthaBatu Madinding. Guru Sekolah Madrasah Salafiyah WusthaBatu Madinding mengikuti kegiatan mengajar setiap hari minggu-jum'at.

Pengajaran dilakukan mulai dari pukul 07.30 -13.00.setiap pagi hari siswa sebelum masuk kelas berkumpul di mesjid kemudian membaca iqrar sholawatan, dan melakukan sholat Dhuha. Diluar jam mengajar guru mendapatkan jadwal piket khusus bagi guru laki-laki dan guru Madrasah Salafiyah WusthaBatu Madinding pada hari-hari tertentu melakukan ngaji Juz Amma dan kitab kuning (tentang kehidupan seharihari), serta rapat dengan para guru dan yayasan Sekolah Madrasah Salafiyah WusthaBatu Madinding (data observasi, 2020).

Dalam menciptakan seorang pendidik atau guru yang bermutu pada Sekolah Madrasah Salafiyah WusthaBatu Madinding menggunakan beberapa strategi dan cara. Sekolah Madrasah Salafiyah WusthaBatu Madinding merencanakan beberapa program yang dimana program-program tersebut direncanakan dan disusun oleh pihak 
yayasan sendiri bukan dari kepala sekolah atau para guru.

Program dan agenda dalam menciptakan guru yang bermutu pada Sekolah Madrasah Salafiyah WusthaBatu Madinding, mengagendakan kegiatan pelatihannya pada 2 dan 3 bulan sekali secara rutin. Beberapa cara Sekolah Madrasah Salafiyah WusthaBatu Madinding dalam menciptakan guru bermutu, yang pertama denganmenganalisis kekurangan yang bermutu pada Sekolah dengan menggunakan beberapa strategi dan cara dalam mencari permasalahan yang guru dan siswa dihadapi oleh guru dalam melaksanakan tugasnya sebagai pendidik. Kegiatan menganalisis ini dilaksanakan secara rutin selama 2 bulan sekali, agar guru tidak merasa terbebani dan merasa mendapatkan masalah dalam proses pembelajaran dan pendidikan.

Setelah itu mengajak guru berinteraksi dan berkomunikasi dengan pihak luar, diantaranya:

1. Melaksanakan studi banding ke Sekolah lainnya yang relevan dan notabene nya lebih berkembang dan maju.

2. Mengirim guru dan staf dalam kegiatan pelatihan dan seminar dalam rangka memperkaya wawasan dan keilmuan guru.

3. Menyelenggarakan pelatihan dengan pihak pusat Sekolah Madrasah Salafiyah yaitu dengan Kementerian Agama yang ada di Mandailing Natal maupun daerah lainya di luar Kabupaten (data wawancara dengan Ibu nur wasli).

Sekolah Madrasah Salafiyah WusthaBatu Madinding merencanakan beberapa program yang dimana program-program tersebut direncanakan dan disusun oleh pihak yayasan sendiri bukan dari kepala sekolah atau para guru.Sekolah Madrasah Salafiyah WusthaBatu Madinding selain menjadikan guru bermutu atau berkualitas, juga menciptakan guru hebat.

Pihak yayasan dan stakeholder untuk mencetak guru yang berkualitas dan hebat merencanakan beberapa program khusus untuk semua guru yang ada di Sekolah Madrasah Salafiyah WusthaBatu Madinding, diantaranya (data dokumentasi sekolah, 2020):

Tabel 4.8

Program Pelatihan Guru

\begin{tabular}{|c|c|l|c|}
\hline No & Waktu & $\begin{array}{l}\text { Program Kerja } \\
\text { Pertemuan }\end{array}$ & Alternatif tanggal \\
\hline 1 & 2 x Pertemuan 1 hari & Menjadi Guru Hebat & $\begin{array}{l}\text { 26 Desember 2019 } \\
\text { \&16 Agustus 2019 }\end{array}$ \\
\hline 2 & 1 x Pertemuan 3 hari & $\begin{array}{l}\text { Workshop Tematik } \\
\text { dan Learning Plan }\end{array}$ & 24-26 April 2019 \\
\hline 3 & 1 x Pertemuan1 hari & $\begin{array}{l}\text { Bersih Rapai dan } \\
\text { tertata }\end{array}$ & 27 Desember 2019 \\
\hline 4 & 2 x Pertemuan2 hari & $\begin{array}{l}\text { Belajar Bersama } \\
\text { Pesantren Thoriqotul }\end{array}$ & $\begin{array}{l}\text { 24-25 Desember } \\
\text { 2018\& 14-15 }\end{array}$ \\
\hline
\end{tabular}




\begin{tabular}{|c|l|l|l|} 
& & & Agustus 2019 \\
\hline 5 & $1 \times$ Pertemuan2 hari & $\begin{array}{l}\text { Strategi Matematika } \\
\text { games }\end{array}$ & $\begin{array}{l}14-11 \text { September } \\
2018\end{array}$ \\
\hline 6 & $2 \times$ Pertemuan & $\begin{array}{l}\text { Tematik } \\
\text { danlearningPlan }\end{array}$ & $\begin{array}{l}13 \text { September } \\
\text { Agustus 2019 } 24\end{array}$ \\
\hline 7 & $1 \times$ Pertemuan & $\begin{array}{l}\text { Belajar } \\
\text { learningEnglis }\end{array}$ & 23 Mei 2019 \\
\hline 8 & $1 \times$ pertemuan & $\begin{array}{l}\text { Strategi matematika } \\
\text { Games }\end{array}$ & 25 Desember 2019 \\
\hline 9 & $2 \times$ Pertemuan & Guru Hebat & $\begin{array}{l}\text { 26 Desember 2018 } \\
\text { \& 15 Agustus 2019 }\end{array}$ \\
\hline 1 & 1 x pertemuan2 hari & $\begin{array}{l}\text { Art and Creativity } \\
- \text { Workshop belajar } \\
\text { Kreatif }\end{array}$ & $\begin{array}{c}\text { 12-13 September } \\
\text { 2018 }\end{array}$ \\
\hline 4
\end{tabular}

Sumber Data : Data Statistik Pesantren Thoriqotul Mardiyah

Program-program guru yang tertuang diatas, ditentukan dan ditetapkan oleh pihak yayasan sendiri, didesain dan dilaksanakan secara rutin dengan tujuan menciptakan guru bermutu dan berkualitas sesuai dengan yang diharapkan oleh Sekolah Madrasah Salafiyah Wustha. Program-program tersebut juga diadakan untuk meningkatkan mutu guru secara keseluruhan.

\section{Kesimpulan}

Perencanaan Madrasah Salafiyah Wustha terhadap peningkatan mutu guru di Madrasah Salafiyah Wustha Batu Madinding dilaksanakan dengan beberapa kegiatan di antaranya: 1) Melaksanakan rapat dengan melibatkan komponen madrasah di antaranya kepala madrasah, wakil kepala madrasah, staf dan guru-guru, 2) Menyusun program kerja bersama terutama program kerja peningkatan mutu guru dan madrasah. Semua komponen Madrasah Salafiyah Wustha ini saling bekerjasama merencanakan peningkatan mutu guru di Madrasah Salafiyah Wustha Batu Madinding. Adapun tujuan dari disusun-nya perencanaan peningkatan mutu guru secara bersama-sama adalah untuk menghindari kesalahan dan kegagalan yang tidak diinginkanMadrasah Salafiyah Wustha menentukan rencana peningkatan mutu guru serta meningkatkan efektivitas dan efisiensi pelaksanaannya. 


\section{REFERENSI}

Nurkholis, Pendidikandalam Upaya Memajukan Teknologi”, Jurnal Kependidikan, Vol. 1 No. 1 Tarbiyah STAIN Purwokerto, November 2013.

Abdul Jalil, "Karakter Pendidikan untuk Membentuk Pendidikan Karakter", NadwaJurnal Pendidikan Islam ,Vol. 6, Nomor 2, Oktober 2012.

Fata Asyrofi Yahya, Pendidikan Tentang Problem Manajemen Pesantren, Sekolah, Madrasah: Problem Mutu dan Kualitas Input-Proses-Output.Jurnalel-Tarbawi Volume VIII, No.1, 2015

Jiddy Masyfu',J.Kebijakan Pemerintah dalam Meningkatkan Mutu Pendidik Pendidikan Agama Islam. DAR EL-ILMI, Jurnal Studi Keagamaan, Pendidikan DanHumaniora, 4(2)188207,Retrievedfromhttp://ejurnal.unisda.ac.id/index.php/dar/article/view/777MoreCitati on Formats Issue Vol 4 No 2 (2017), h.10-20

Siswanto,Desain Mutu Pendidikan Pesantren,KARSA: Jurnal Sosial dan Budaya Keislaman. Vol. 23 No. 2, Desember 2015: 258-274

Siti Makhmudah, Upaya Memperbaiki Kualitas Guru DenganMemaksimalkan Terpenuhinya Kompetensi Kepribadian Dan Profesionalisme Guru, Jurnal Studi Islam, Volume 11, No. 1 April 2016

Azyumardi Azra, (2000) Paradigma Baru Pendidikan Nasional; Rekonstruksi dan Demokrasi, (Jakarta: Kompas, 2002), Cet.1, h. xvii Moh. Uzer Usman, Menjadi Guru Professional, Bandung: PT Remaja Rosda Karya.

Warih Jatirahayu, Guru Berkualitas Kunci Mutu Pendidikan,Jurnal Ilmiah Guru "COPE”, SMP Negeri 4 Sleman, Kab. Sleman No. 02/Tahun XVII/Nopember 2013

Ijudin, Pengembangan Konsep Mutu Pendidikan Pondok PesantrenJurnal Pendidikan Universitas Garut Fakultas Pendidikan Islam dan Keguruan, Vol. 09; No. 01; 2015, h. 15-32

Sitti Nurfaidah Samad,Manajemen Mutu Pendidikan Berbasis Pesantren (Studi Kasus Ma Al Mawaddah Warrahmah Kolaka), Jurnal Teknologi Pendidikan Madrasah (2019) 2 (1), h.70 88

Dirjen Pendidikan Islam, Kementerian Agama RI, Undang-undang dan Peraturan Pemerintah RI tentang Pendidikan, (Jakarta:2013), h 24.

Ruma Mubarok,Manajemen Mutu Guru Pondok Pesantren,Fakultas Ilmu Tarbiyah dan Keguruan,Jurnal MPI UIN Maulana Malik Ibrahim Malang Vol 1, No 2, 2016 
Tim Penyusun, Undang-Undang No.14/2005, tentang Guru dan Dosen, (Bandung: Nuansa Aulia, 2006), h. 6

Abdul Hadis \& Nurhayati, Manajemen Mutu Pendidikan, h. 3-4

Sujana, Nana (2006). EvaluasiPendidikan, Jakarta: Pers

Alinuh, Kepala Madrasah Salafiyah Batu Madinding, Wawancara, tanggal 25 April 2020. 